\title{
Squirreltail Seed Germination
}

JAMES A. YOUNG AND RAYMOND A. EVANS

Highlight: Germination tests on squirreltail seed showed that three temperature regimes always produced optimum germination of 76 to $100 \%$. We defined optimum as not statistically $(p=$ 0.01) different from maximum. The always optimum temperature regimes were: (1) a constant $15^{\circ} \mathrm{C}$, (2) alternating $10 / 15^{\circ} \mathrm{C}(16$ hours cold/ 8 hours warm each day), and (3) $10 / 20^{\circ} \mathrm{C}$. When seed was produced in a year with good growing conditions, optimum germination extended over a wide range of temperatures. At optimum temperatures, the rate of germination was very rapid with a high percentage of total germination occurring within a week. The lack of inherent germination requirements that restrict germination, high germinability, and a rapid rate of germination help to explain the colonizing ability of this species.

Squirreltail (Sitanion hystrix var. hystrix) is widespread in the western United States (Hitchcock 1950). This caespitose perennial grass is characterized by bristly spikes with disarticulating joints. Ecologically, squirreltail is a seral species that often increases in response to disturbance. Occasionally it is abundant on disturbed areas, but it is mainly of scattered occurrence (Forest Service 1937). The successional role of this species is illustrated in the Pacific Northwest by its reported occurrence in at least 25 plant communities of different potentials, while being a dominant species in only 2 communities (Franklin and Dyrness 1973). What kind of germination system allows squirreltail to colonize in so many different sites?

Squirreltail is an exceedingly variable species (Stebbins et al. 1946). Some localities may contain many different "races" which can be recognized on the basis of slight differences in external morphology and habitat preference (Stebbins 1972). The races of squirreltail are adapted to a wide range of environmental conditions (Wilson 1963). The variable forms can be separated from each other by barriers of hybrid incompatibility or sterility and constitute sibling species. Does this variability extend to germination requirements?

The disarticulating rachis makes seed collection difficult, although the seeds of squirreltail were important in the diet of hunter-gatherer Indians in the Great Basin (Steward 1938). If the seeds could be collected in quantity, the ecologic characteristics that permit this species to increase in abundance with disturbance seem to make it a desirable candidate for seeding on disturbed sites. Knowledge of germination characteristics will aid in the use of squirreltail as a revegetation species.

The authors are range scientists, Agricultural Research Service, U.S. Department of Agriculture, University of Nevada, Renewable Resources Center, Reno 89512.

The work represents cooperative investigations of the Agricultural Research Service, U.S. Department of Agriculture, and the Agricultural Experiment Station, University of Nevada, Reno. Journal Series No. 311.

The authors wish to express their appreciation to B. L. Kay, University of California, and M. Hironaka, University of Idaho, for reviewing and making suggestions that improved this report.

Manuscript received January 12, 1976.
Our purpose was to investigate the ecology of germination of squirreltail seeds (caryopses).

\section{Methods}

Germination trials were conducted from 1967 through 1975. In all tests, four replications of 100 seeds each were used. We started in 1967 with constant and alternating temperature regimes of 0,2 , and $5^{\circ} \mathrm{C}$ and 5-degree increments through $30^{\circ} \mathrm{C}$. In each 24 -hour period, each temperature regime consisted of 16 hours at each low temperature and 8 hours at all possible higher combinations. This 8 -hour warm and 16-hour cold diurnal fluctuation corresponds to the natural regime in seedbeds of the central Great Basin during the periods when moisture is available for germination (Evans and Young 1972). By 1970, we had developed equipment to add sub-zero temperatures of $-6,-4$, and $-2^{\circ} \mathrm{C}$ to the regimes tested (Evans et al. 1970b). The maximum temperature was incrcased to $40^{\circ} \mathrm{C}$ in 1970 . In 1974 , we added a $35^{\circ} \mathrm{C}$ temperature.

Seeds with awns intact were placed in petri dishes on top of germination paper and kept moist with tap water. Seeds were considered germinated when the radicle cmerged $5 \mathrm{~mm}$. Tests were conducted for 4 weeks. Germination counts were made at least once a week and in some tests, daily.

Seeds of all sources were tested within 1 month after harvest and again at 3 and 6 months to determine the possible occurrence of afterripening requirements. Numerous collections of seed from different locations in Nevada and northeastern California were tested. Each collection was made from as many plants as possible. In 1967, seed was collected from each location only once. In subsequent years, we collected several times during the 1- to 2-week maturity period Germination of these collections was compared at constant temperatures from 2 to $30^{\circ} \mathrm{C}$, and the optimum germination collection was used for further tests. This procedure was used to avoid collecting immature seeds and to make sure we had some secd before the rachis disarticulated and blew away. We tried to collect seeds annually from the same community located at Medell Flat, $35 \mathrm{~km}$ north of Reno, Nev Unfortunately, no seeds were produced at this site in drier years 1968 1970 , and 1972 .

In 1974, we conducted germination trials with three sources of squirreltail seed collected near Reno, Nev. In this experiment germinating seedlings were counted daily for the first 7 days and then at weekly intervals through 4 weeks. To express the rate of germination of squirreltail seeds at a given temperature, we used coefficients of germination (CRG) (Maguire 1962). The formula may be written

$$
\mathrm{CRG}=\sum_{\mathrm{i}}^{\mathrm{n}}\left[\mathrm{g}_{\mathrm{n}}-\mathrm{g}_{(\mathrm{n}-1)} / \mathrm{n}\right]
$$

where $g_{n}$ is the accumulated germination on a given day minus the germination percentage on the previous day $\left[g_{(n-1)}\right]$ divided by the number of incubation days $(n)$. The larger the CRG, the greater the aggregate rate of germination.

We compared the germination of awned and artificially deawned seeds collected in 1974 from Medell Flat. The awns were removed with a hammermill. 
Table 1. Mean germination (\%) of squirreltail seed in relation to constant and alternating temperature regimes. Seed produced in 5 different years. ${ }^{a}$

\begin{tabular}{|c|c|c|c|c|c|c|c|c|c|c|}
\hline \multirow{2}{*}{$\begin{array}{c}\text { Cold (16 hours) } \\
\text { temperature } \\
\left({ }^{\circ} \mathrm{C}\right)\end{array}$} & \multicolumn{10}{|c|}{ Warm (8 hours) temperature $\left({ }^{\circ} \mathrm{C}\right)$} \\
\hline & 0 & 2 & 5 & 10 & 15 & 20 & 25 & 30 & 35 & 40 \\
\hline-6 & $0 \mathrm{q}$ & $0 \mathrm{q}$ & $0 \mathrm{q}$ & $0 q$ & $0 \mathrm{q}$ & $0 q$ & $0 q$ & $0 \mathrm{q}$ & $0 \mathrm{q}$ & $0 \mathrm{q}$ \\
\hline-4 & $0 \mathrm{q}$ & $0 \mathrm{q}$ & $0 \mathrm{q}$ & $0 \mathrm{q}$ & $0 \mathrm{q}$ & $0 \mathrm{q}$ & $0 \mathrm{q}$ & $0 \mathrm{q}$ & $0 \mathrm{q}$ & $0 \mathrm{q}$ \\
\hline-2 & $0 \mathrm{q}$ & $0 \mathrm{q}$ & $0 \mathrm{q}$ & $12 \mathrm{n}-\mathrm{p}$ & $31 \mathrm{k}-\mathrm{m}$ & 15 n-p & $211-0$ & $3 \mathrm{pq}$ & $0 \mathrm{q}$ & $0 \mathrm{q}$ \\
\hline 0 & $0 \mathrm{q}$ & $0 \mathrm{q}$ & $0 \mathrm{q}$ & 16 n-p & $35 \mathrm{j}-1$ & $201-0$ & $211-0$ & $10 \mathrm{n}-\mathrm{p}$ & $2 \mathrm{pq}$ & $0 \mathrm{q}$ \\
\hline 2 & & $42 \mathrm{i}-\mathrm{k}$ & $59 \mathrm{f}-\mathrm{h}$ & $67 \mathrm{~d}-\mathrm{g}$ & $68 c-f$ & $71 \mathrm{c}-\mathrm{f}$ & $67 \mathrm{~d}-\mathrm{g}$ & $55 \mathrm{~g}-\mathrm{j}$ & $2 \mathrm{pq}$ & $0 \mathrm{q}$ \\
\hline 5 & & & $64 \mathrm{c}-\mathrm{g}$ & $18 \%$ & $4 \%$ & wh & $\%$ & $72 \mathrm{c}-\mathrm{f}$ & $211-0$ & $1 \mathrm{q}$ \\
\hline 10 & & & & 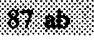 & $6 \%$ & (1). & (39). & 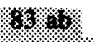 & $39 \mathrm{jk}$ & $10 \mathrm{o}-\mathrm{q}$ \\
\hline 15 & & & & & 64 & 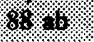 & 48. & 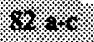 & 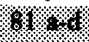 & $46 \mathrm{~h}-\mathrm{j}$ \\
\hline 20 & & & & & & $82 \mathrm{a}-\mathrm{c}$ & $81 \mathrm{a}-\mathrm{d}$ & 77 a-e & $52 \mathrm{~g}-\mathrm{j}$ & $57 \mathrm{~g}-\mathrm{i}$ \\
\hline 25 & & & & & & & $72 c-k$ & 74 b-e & $46 \mathrm{~h}-\mathrm{j}$ & $50 \mathrm{~h}-\mathrm{j}$ \\
\hline 30 & & & & & & & & $47 \mathrm{~h}-\mathrm{j}$ & $28 \mathrm{k}-\mathrm{n}$ & $291-n$ \\
\hline 35 & & & & & & & & & $2 p q$ & $2 q$ \\
\hline 40 & & & & & & & & & & $0 \mathrm{q}$ \\
\hline
\end{tabular}

aMeans followed by the same letter are not significantly different at the 0.01 level of probability as determined by Duncan's multiple range test. Overall means compared by using pooled error mean square, following procedures ' of Cochran and Cox (1950). Optimum germination percentages, those not significantly $(p=0.01)$ different from maximum, are shaded for readers convenience.

Seeds of squirreltail from a 197 I collection that was previously determined to germinate at $90 \%$ were planted in clay and sandy loam seedbeds. Seeds were planted on the soil surface, barely covered by soil and beneath the surface at $0.5,1,2,3,4,5,6$, and $8 \mathrm{~cm}$. The beds were prepared using procedures previously described to obtain bulk density similar to field profiles (Young et al. 1969b).

Seeds from the same source used in the emergence experiment were planted on the surface of sandy loam and clay beds and covered with 1 $\mathrm{cm}$ of annual grass litter, and on the surface of $1 \mathrm{~cm}$ of litter.

\section{Results}

\section{Germination at Constant and Alternating Temperatures}

There was considerable variability in germination among locations and within one location among years in relation to constant and alternating temperatures.

Only three temperature regimes, $10 / 15\left(10^{\circ} \mathrm{C}\right.$ for 16 hours and $15^{\circ} \mathrm{C}$ for 8 hours in each 24 -hour period), $10 / 20$, and $15 / 15^{\circ} \mathrm{C}$ were never significantly different $(p=0.01)$ from the optimum in percentage germination (Fig. 1). Clustered around these always optimum germination temperatures were six regimes where, $80 \%$ of the time, total germination was not significantly lower than the optimum. Twenty-six temperature regimes

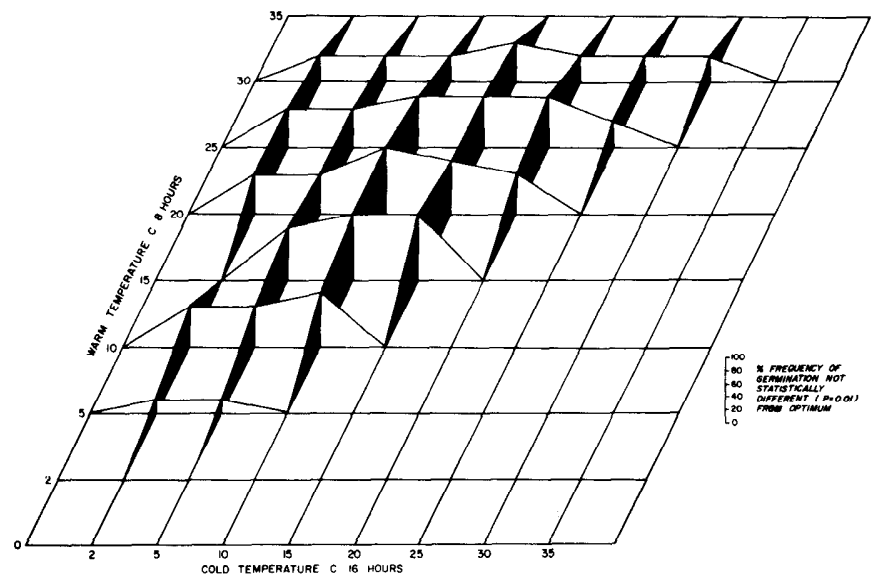

Fig. 1. Frequency (\%) of occurrence of germination of squirreltail seeds not statistically $(\mathrm{p}=0.01)$ different from the maximum at constant and alternating temperature regimes. provided germination conditions where, at least once, total germination was not significantly lower than the optimum. These temperatures include $48 \%$ of the temperature regimes used above $0^{\circ} \mathrm{C}$. Squirreltail truly has the inherent potential for copious germination over a wide range of temperatures.

If we compare mean germination for all tests, the optimum temperature regimes fall in the $5,10,15$, or $20^{\circ} \mathrm{C}$ cold periods, alternating with 10 to $35^{\circ} \mathrm{C}$ warm periods (Table 1).

\section{Variability among Years}

Seeds of squirreltail produced in different years in the same community at Medell Flat did not have identical germination

Table 2. Constant and alternating temperature regimes where germination of squirreltail seeds was not significantly $(p=0.01)$ different from the maximum among 3 years' seed production from the same plant community located at Medell Flat.

\begin{tabular}{|c|c|c|c|}
\hline \multirow{2}{*}{$\begin{array}{l}\text { Temperature } \\
\text { regimes }\left({ }^{\circ} \mathrm{C}\right) \\
\text { cold } 16 \text { hours/ } \\
\text { warm } 8 \text { hours }\end{array}$} & \multicolumn{3}{|c|}{ Optimum temperatures for germination } \\
\hline & 1969 & 1971 & 1973 \\
\hline $2 / 10$ & & $\mathrm{X}$ & \\
\hline $2 / 15$ & & $X$ & $X$ \\
\hline $2 / 20$ & & $\mathrm{X}$ & $\mathrm{X}$ \\
\hline $2 / 25$ & & $X$ & $X$ \\
\hline $2 / 30$ & & $X$ & $X$ \\
\hline $5 / 10$ & & & $\mathrm{X}$ \\
\hline $5 / 15$ & & $X$ & $X$ \\
\hline $5 / 20$ & & $\mathrm{X}$ & $\mathrm{X}$ \\
\hline $5 / 25$ & & & $x$ \\
\hline $5 / 30$ & & & $\mathrm{X}$ \\
\hline $10 / 10$ & $\mathrm{X}$ & & $\mathrm{X}$ \\
\hline $10 / 15$ & $\mathrm{X}$ & $X$ & $\mathrm{X}$ \\
\hline $10 / 20$ & $\mathrm{X}$ & $\mathbf{X}$ & $\mathbf{X}$ \\
\hline $10 / 25$ & $\mathrm{X}$ & & $\mathrm{X}$ \\
\hline $10 / 30$ & $\mathrm{X}$ & & \\
\hline $15 / 15$ & $X$ & $\mathrm{X}$ & $\mathrm{X}$ \\
\hline $15 / 20$ & $\mathrm{X}$ & $\mathrm{X}$ & $\mathrm{X}$ \\
\hline $15 / 25$ & $\mathrm{X}$ & $X$ & $\mathrm{X}$ \\
\hline $15 / 30$ & $\mathrm{X}$ & $\mathrm{X}$ & $\mathrm{X}$ \\
\hline $20 / 20$ & $\mathrm{X}$ & $X$ & $\mathrm{X}$ \\
\hline $20 / 25$ & $\mathrm{X}$ & $\mathrm{X}$ & $\mathrm{X}$ \\
\hline $20 / 30$ & $\mathrm{X}$ & & $\mathrm{X}$ \\
\hline $25 / 25$ & $X$ & & $\mathrm{X}$ \\
\hline $25 / 30$ & $X$ & & $\mathrm{X}$ \\
\hline $30 / 30$ & $\mathrm{X}$ & & $\mathrm{X}$ \\
\hline
\end{tabular}


responses in relation to temperatures. In 1969 , germination at any $5^{\circ} \mathrm{C}$ cold period was markedly lower than the optimum range. We define optimum as not statistically $(p=0.01)$ different from the maximum. The optimum range extended into the regimes with 25 and $30^{\circ} \mathrm{C}$ cold temperatures (Table 2 ). In contrast, in 1971 using seed from the same community, the optimum germination range extended into regimes with $2^{\circ} \mathrm{C}$ cold period temperatures but not into the 25 or $30^{\circ} \mathrm{C}$ cold period regimes.

Further examples of the among-year variability in germination are provided by seed collected from the same Medell Flat community in 1973. The optimum germination range extended from 2 to $30^{\circ} \mathrm{C}$ cold periods (Table 2 ), essentially encompassing or exceeding the variability noted in the two previous contrasting tests.

This germination response indicates that a given population of squirreltail produces seed having the inherent potential for consistent copious germination at a relatively limited range of temperatures. Because of favorable precipitation and temperature in any one year, high germination may extend over a large range of temperature regimes besides the relatively few that are always optimum. In dry years, no or very little seed is produced, and presumably the seed that is produced has a much more restrictive germination response.

\section{Germination at Extreme Temperatures}

A constant $40^{\circ} \mathrm{C}$ always inhibited germination of squirreltail seed (Table 1). To obtain germination with $40^{\circ} \mathrm{C}$ warm periods, the remainder of the diurnal cycle had to be $5^{\circ} \mathrm{C}$ or above (Table 1). To obtain relatively high amounts of germination, the cold period had to be above $10^{\circ} \mathrm{C}$ and below $30^{\circ} \mathrm{C}$ alternating with $40^{\circ} \mathrm{C}$.

In terms of successful seedling establishment in sagebrush/ bunchgrass communities, germination under cold extremes is of paramount importance (Evans et al. 1970a). The coldest extreme where germination occurred was $-4 / 15^{\circ} \mathrm{C}$ (Table 1). Decreasing the cold minimum to $-6^{\circ} \mathrm{C}$ severely inhibited germination. Increasing the cold minimum to $-2^{\circ} \mathrm{C}$ resulted in germination from 10 to $30^{\circ} \mathrm{C}$ in 2 years of testing seed from Medell Flat.

Germination at $0 / 15^{\circ} \mathrm{C}$ ranged from 0 to $83 \%$. Usually germination occurred from 10 to $30^{\circ} \mathrm{C}$ with $0^{\circ} \mathrm{C}$ cold periods. The $0^{\circ} \mathrm{C}$ regimes are important in considering potential germination under snow cover (Bleak 1959; Hull 1960).

\section{Afterripening}

Freshly harvested seeds of squirreltail had just as good germination as seeds stored for 3 months, providing the seeds were fully mature when harvested (data not shown). Afterripening requirements that are temperature related are common with range grasses (Laude 1956). Generally, some of the most successful colonizers in disturbed sagebrush/bunchgrass communities do not have any afterripening requirements. Downy brome (Bromus tectorum) and tumble mustard (Sisymbrium altissimum) are examples of aliens that have preempted native seral roles and do not have habitat restriction imposed by afterripening requirements (Young et al. 1970).

\section{Rate of Germination}

At a constant $15^{\circ} \mathrm{C}$ there was no germination as evidenced by radicle emergence until 5 days incubation had elapsed (Table 3 ). With one more day of incubation, germination increased 10 times. Germination increased gradually until 14 days incu-
Table 3. Average rate of germination (\%) and coefficients of rate of germination for three sources of seeds of squirreltail collected in $1974 .^{\mathrm{a}}$

\begin{tabular}{lrrrrrrrrrr}
\hline \multirow{2}{*}{$\begin{array}{c}\text { Days } \\
\text { incubation }\end{array}$} & \multicolumn{10}{c}{ Constant temperatures $\left({ }^{\circ} \mathrm{C}\right)$} \\
\hline & 2 & 5 & 10 & 15 & 20 & 25 & 30 & 35 & 40 \\
\hline 3 & 0 & 0 & 0 & 0 & 0 & 0 & 0 & 0 & 0 \\
4 & 0 & 0 & 0 & 0 & 1 & 7 & 2 & 0 & 0 \\
5 & 0 & 0 & 0 & 5 & 24 & 21 & 9 & 0 & 0 \\
6 & 0 & 0 & 13 & 54 & 58 & 48 & 24 & 0 & 0 \\
14 & 0 & 60 & 82 & 82 & 77 & 63 & 36 & 0 & 0 \\
28 & 26 & 77 & 85 & 85 & 78 & 65 & 37 & 0 & 0 \\
$\begin{array}{l}\text { Coefficient } \\
\text { of rate of } \\
\text { germination }\end{array}$ & 0.92 & 4.88 & 7.18 & 11.26 & 11.89 & 10.19 & 5.07 & 0 & 0 \\
\hline
\end{tabular}

${ }^{2}$ Coefficient of rate of germination (CRG) calculated with formula

$$
\mathrm{CRG}=\sum_{\mathrm{i}}^{\mathrm{n}}\left[\mathrm{g}_{\mathrm{n}}-\mathrm{g}_{(\mathrm{n}-1)} / \mathrm{n}\right]
$$

where $g_{n}$ is the accumulated germination on a given day minus the germination percent on the previous day $\lg _{(n-1)]}$ divided by the number of days incubation $(n)$. The larger the CRG, the greater the rate of germination.

bation. Essentially all germination occurred by 14 days and 2 weeks additional incubation resulted in only $3 \%$ more total germination. Raising the incubation temperature to $25^{\circ} \mathrm{C}$ speeded the rate of germination through 5 days. Reducing the incubation temperature to $2^{\circ} \mathrm{C}$ required 28 days for germination to occur. The fastest germination (CRG) occurred at $20^{\circ} \mathrm{C}$ (Table 2). The $\mathrm{CRG}$ for 15 and $25^{\circ} \mathrm{C}$ were similar with a noticeable reduction at lower temperatures and at $30^{\circ} \mathrm{C}$.

\section{Deawned Seeds}

Removal of the long awns by using a hammerhill did not alter the germination characteristics of squirreltail seeds (data not shown). Care must be taken not to damage the embryo end of the caryopses. Deawning of the seed would be necessary for mechanical drilling.

\section{Emergence from Soil and Litter}

Squirreltail seeds that were barely covered emerged or germinated much better than seeds left on the soil surface (Table 4). The failure of seeds to germinate on the surface is undoubtedly a function of moisture relationships (Evans and Young 1972). This failure of seeds to germinate on the soil surface is a constant feature of all semiarid rangeland seedbeds and emphasizes the importance of litter and microtopography in controlling germination. Burial of seed $1 \mathrm{~cm}$ deep markedly lowered emergence in the clay soil, while there was no marked reduction with $2 \mathrm{~cm}$ of burial in the loam soil. Emergence was very slight at $5-\mathrm{cm}$ burial and $6 \mathrm{~cm}$ eliminated all emergence.

Table 4. Emergence (\%) of squirreltail seedlings from clay and loam seedbeds in relation to depth of planting. ${ }^{a}$

\begin{tabular}{lll}
\hline Planting & \multicolumn{2}{c}{ Soil } \\
\cline { 2 - 3 } depth & Clay & Loam \\
\hline $\begin{array}{l}\text { Surface } \\
\text { Barely covered }\end{array}$ & $50 \mathrm{c}$ & $10 \mathrm{ef}$ \\
$1 \mathrm{~cm}$ & $81 \mathrm{ab}$ & $87 \mathrm{a}$ \\
$2 "$ & $57 \mathrm{bc}$ & $87 \mathrm{a}$ \\
$3 "$ & $31 \mathrm{~d}$ & $88 \mathrm{a}$ \\
$4 "$ & $24 \mathrm{de}$ & $72 \mathrm{~b}$ \\
$5 "$ & $5 \mathrm{ef}$ & $25 \mathrm{de}$ \\
$6 "$ & $2 \mathrm{f}$ & $2 \mathrm{f}$ \\
$8 "$ & $0 \mathrm{f}$ & $0 \mathrm{f}$ \\
\hline
\end{tabular}

Means followed by the same letter are not significantly different at the 0.01 level of of probability as determined by Duncan's multiple range test. 
Table 5. Establishment (\%) of squirreltail seedlings in relation to seed coverage with soil and/or litter on clay and loam soils. ${ }^{a}$

\begin{tabular}{lcc}
\hline & \multicolumn{2}{c}{ Soil } \\
\cline { 2 - 3 } Treatment & Clay & Loam \\
\hline Soil surface-bare & $45 \mathrm{~b}$ & $8 \mathrm{c}$ \\
$1 \mathrm{~cm}$ deep & $87 \mathrm{a}$ & $86 \mathrm{a}$ \\
Soil surface-1 cm litter & $86 \mathrm{a}$ & $91 \mathrm{a}$ \\
$1 \mathrm{~cm}$ deep-1 cm litter & $81 \mathrm{a}$ & $80 \mathrm{a}$ \\
Surface of $1 \mathrm{~cm}$ litter & $35 \mathrm{~b}$ & $12 \mathrm{c}$ \\
\hline
\end{tabular}

Means followed by the same letter are not significantly different at the 0.01 level of probability as determined by Duncan`s multiple range test.

Squirreltail seeds emerged through $1 \mathrm{~cm}$ of litter if they were buried in soil or not (Table 5). However, if they were placed on the surface of the litter, germination was markedly reduced. This reduction persisted in spite of the long slender caryopses that appeared ideal to work down through litter accumulations to the mineral soil. Grass caryopses vary greatly in their response to germination in litter (Young et al. 1971). This type of germination is extremely important in sagebrush/bunchgrass communities, where most of the reproductive reserve of seeds lics on the soil surface in the scant accumulations of litter (Young et al. 1969a).

\section{Discussion}

Given adequate temperatures and moisture for growth, squirreltail plants produce an abundance of highly germinable seeds. Although squirreltail is not the most desirable forage species, it has the advantage of producing abundant seeds that will germinate. Many of our native perennial grasses produce few seeds and those often have restrictive seed dormancy requirements.

Squirreltail is a competitive species, as evidenced by its increase in the face of alien annual grass competition in southern Idaho, when areas were kept free of grazing and rodent disturbance (Hironaka and Tisdale 1963). Hironaka and Sindelar (1975) consider squirreltail to be a successful invader of annual grass stands that would be closed to exotic wheatgrasses (Agropyron spp.). Therefore, the lack of restrictive inherent requirements for germination must be a competitive advantage.

Production of abundant crops of germinable seeds under wildland conditions does not automatically make squirreltail an economically feasible revegetation species. For squirreltail to be a commercial product, seed must be produced every yearnot just in the wet years. The seeds must be harvestable. This means finding selections without a disarticulating rachis or developing special harvesting equipment to pick the seed up off the ground. Special seed processing techniques are necessary to remove the awn without damaging the germinability of the seeds.

Despite the high germinability of squirreltail seeds over a broad range of temperatures, we must remember that lack of moisture on the surface of a seedbed will limit establishment just as effectively as will extreme temperatures. Rapid physiologic development of squirreltail seedlings helps to insure successful establishment (Hironaka and Sindelar 1973). Provide seedbed conditions conducive to germination in regard to moisture condition and there is a good possibility of increasing the density of squirreltail.

\section{Literature Cited}

Bleak, A. T. 1959. Germination characteristics of sceds under snow. J. Range Manage. 12:298-302.

Cochran, W. G., and G. M. Cox. 1950. Experimental Design. John Wiley and Sons, New York. $454 \mathrm{p}$.

Evans, R. A., H. R. Holbo, R. E. Eckert, Jr., and J. A. Young. 1970a. Functional environment of downy brome communities in relation to weed control and revegetation. Weed Sci. 18:154-162.

Evans, R. A., J. A. Young, R. Henkel, and G. J. Klomp. 1970b. A low temperature gradient bar for seed germination studies. Weed Sci. 18:575-576.

Evans, R. A., and J. A. Young. 1972. Microsite requirements for establishment of annual rangeland weeds. Weed Sci. 20:350-356.

Forest Service. 1937. Range plant handbook. Forest Serv., U.S. Dep. Agr., Washington, D.C.

Franklin, J. G., and C. T. Dyrness. 1973. Natural vegetation of Oregon and Washington. U.S. Dep. Agr., Forest Serv. General Tech. Rep. PNW-8. 417 p.

Hironaka, M., and B. W. Sindelar. 1973. Reproductive success of squirreltail in medusahead infested ranges. J. Range Manage. 26:219-221.

Hironaka, M., and B. W. Sindelar. 1975. Growth characteristics of squirreltail seedlings in competition with medusahead. J. Range Manage. 28: 283-285.

Hironaka, M., and E. W. Tisdale. 1963. Secondary succession in annual vegetation in southern Idaho. Ecology 44:810-812.

Hitchcock, A. E. 1950. Manual of the grasses of the United States. (Second ed. revised by A. Chase.) U.S. Dep. Agr. Misc. Pub. 200. 1051 p.

Hull, A. C., Jr. 1960. Winter germination of intermediate wheatgrass on mountain lands. J. Range Manage. 13:257-260.

Laude, H. M. 1956. Germination of freshly harvested seeds of some western range species. J. Range Manage. 9:126-129.

Maguire, J. D. 1962. Speed of germination-aid in selection and evaluation of seedling emergence and vigor. Crop Sci. 2:176-177.

Stebbins, G. L., Jr. 1972. The evolution of the grass family. In: The Biology and Utilization of Grasses. V. B. Youngner and C. M. McKell (Eds.). Acad. Press. New York. p. 1-17.

Stebbins, G. L., Jr., J. I. Valencia, and R. M. Valencia. 1946. Artificial and natural hybrids in the Gramineae tribe hordeac. I. Elymus, Sitanion, and Agropyron. Amer. J. Bot. 33:338-351.

Steward, J. H. 1938. Basin-Plateau aboriginal sociopolitical groups. Bur. of American Ethnology. Smithsonian Institute Bull. 120. Washington, D.C.

Wilson, F. D. 1963. Revision of Sitanion (Triticaea, Gramineae). Brittonia 15:303-323

Young, J. A., R. A. Evans, and R. E. Eckert, Jr. 1969a. Population dynamics of downy brome. Weed Sci. 17:20-26.

Young, J. A., R. A. Evans, and R. E. Ecker, Jr. 1969b. Emergence of medusahead and other grasses from four seeding depths. Weed Sci. 17: 376-379.

Young, J. A., R. A. Evans, and B. L. Kay. 1971. Germination of caryopses of annual grasses in simulated litter. Agron. J. 63:351-355.

Young, J. A., R. A. Evans, R. O. Gifford, and R. E. Eckert, Jr. 1970. Germination of three species of Cruciferae. Weed Sci. 18:41-48.

\section{CLYDE ROBIN}

NATIVE SEEDS 